\title{
RESTORATION OF PRZEWALSKI'S HORSE (EQIUDAE, PERISSODACTYLA) AT THE BREEDING CENTRE OF THE ASSOCIATION «WILD NATURE OF STEPPE», RUSSIA
}

\author{
Victor A. Minoranskiy ${ }^{1,2}$, Ali M. Uzdenov ${ }^{1}$, Vasily I. Dankov' ${ }^{1}$ Yulia V. Malinovskaya ${ }^{1,2}$ \\ ${ }^{1}$ Association «Wild Nature of Steppe», Russia \\ e-mail: priroda.rostov@yandex.ru \\ ${ }^{2}$ Southern Federal University, Russia \\ e-mail:mgingerm@yandex.ru
}

Received: 20.02.2019. Revised: 15.04.2019. Accepted: 22.04.2019.

\begin{abstract}
The Association «Wild Nature of Steppe» located in Rostov Region (Russia) is engaged in the preservation of rare and valuable animals of the steppe zone. The Association breeding centre is located in a Protected Area, the Rostovsky State Nature Biosphere Reserve. The breeding centre of the Association "Wild Nature of Steppe» (size is $17.34 \mathrm{~km}^{2}$ ) is inhabited by the Bustard (Otis tarda), Bustling (Tetrax tetrax), Kulan (Equus hemionus kulan), Saiga (Saiga tatarica) and other animal species. The tarpan (Equus ferus ferus) lived on the European steppes until the $19^{\text {th }}$ century. In 2013, the Association «Wild Nature of Steppe» transported four adult Przewalski's horses (Equus ferus przewalskii) from the F.E. Falz-Fein Biosphere Reserve «Askania-Nova» (Ukraine). The group consists of one male aged 5, two females aged 6 and one female aged 4 years. The article considers the aspects of transportation of the horses to Rostov Region, their acclimatisation and maintenance. The horses were initially placed in a quarantine pen. In 2014, they were transferred to an enclosure of $0.63 \mathrm{~km}^{2}$, in 2017 they were released into a larger enclosure of $5.12 \mathrm{~km}^{2}$. The article identifies the enclosures for the horses, their nutrition and behaviour. The animals produce offspring annually in the breeding centre of the Association "Wild Nature of Steppe». Currently, there are 14 Przewalski's horses in the breeding centre. This reflects rather favourable conditions for the animals. Three young males are kept separately from the main herd. A study on keeping the horses together with other animals: Kulan, Guanaco (Lama guanicoe), Père David's Deer (Elaphurus davidianus), Water buffalo (Bos bubalis), Domestic yak (Bos grunniens), American Bison (Bison bison) and others was conducted at the breeding centre. The Przewalski's horses successfully share the habitat with the Saiga and Bactrian camel (Camelus bactrianus). In the future it is planned to enlarge the horse enclosure and to bring some new specimens expanding the genetic diversity of the animal stock.
\end{abstract}

Key words: breeding, ecological tourism, Equus ferus przewalskii, Rostov Region, state nature reserve

\section{Introduction}

The tarpan (Equus ferus ferus Antonius, 1912), a species closely related to the Przewalski's horse (Equus ferus przewalskii Poliakov, 1881), has historically inhabited the Don steppes. By the $19^{\text {th }}$ century, intensive human pressure on the European wild horses has resulted in its complete eradication from the wild (Kirikov, 1959). This disrupted biocenotic bonds in natural steppe ecosystems. In 1995 the State Nature Reserve «Rostovsky» (hereafter also Rostovsky Reserve) (Minoransky \& Chekin, 2003) was established in Rostov region to restore and preserve the natural ecosystems of European steppes. Thanks to its activities, to date, natural steppe ecosystems have been restored in anthropogenic desertified lands. At the same time, modern biodiversity in the Rostovsky Reserve differs from that in this territory 100 years or more ago. Among the several causes of this phenomenon is the absence of wild steppe ungulates (Equus ferus Boddaert, 1785 and Saiga tatarica Linnaeus, 1758).
During the twentieth century, a considerable experience in preserving of the Przewalski's horse was accumulated at zoos and breeding centres of different countries. At the meeting of FAO/UNEP experts in Moscow in 1985 it was decided to prepare projects to reintroduce Przewalski's horses into the wild. Since 1986 European institutions keeping this species at breeding centres and zoos participate in the European Endangered Species Programme for the Przewalski's Horse (EEP) and a number of other programmes (Spasskaya, 2016). The first reintroduction of these horses started in China in 1985, in Mongolia in 1992, in Kazakhstan in 2003 (Zimmermann, 2005). However, presently the artificially created populations in the wild have not reached the level of stability, remaining vulnerable to a number of internal and external factors, characterised by slow growth (Spasskaya, 2016).

The State Nature Biosphere Reserve «Rostovsky» acts in close contact with the Associa- 
tion «Wild Nature of Steppe» (hereafter - Association), the field breeding centre (Stationary) for rare and valuable animals, located in this Protected Area. Since 2013 work on maintenance and reproduction of Przewalski's horse has been carried out at the Stationary. The conditions of the natural habitat of the Przewalski's horse differ from those in the area of the Rostovsky Reserve. In addition, the Stationary stock comprises horses whose ancestors were kept in artificial environments in various countries for many generations. Currently, the herd of Przewalski's horse inhabiting the Stationary is the largest in the south of the European part of Russia. The purpose of this study was to investigate the possibilities of maintaining Przewalski's horse under the natural conditions of the Rostovsky Reserve, adaptation of animals to the new area and optimisation of conditions for their reproduction.

\section{Material and Methods}

The Rostovsky Reserve is located in the southeast of the Rostov region (hereinafter $-\mathrm{RR}$ ) in the vicinity of Manich-Gudilo, the largest saltwater lake in Europe and borders the Republic of Kalmykia. A hot dry climate (annual amount of rainfall is $359 \mathrm{~mm}$ (Panov et al., 2009)), frequent dry winds and dust storms, acute lack of fresh water in the past hampered the development of agriculture, and the population was engaged in animal husbandry. In the second half of the 20th century the availability of fresh water, afforestation of steppes positively affected the development of agriculture and the rapid increase of livestock. This led to excessive grazing of steppes by sheep, the emergence of anthropogenic deserts over large areas in the south-eastern regions of RR, Kalmykia and neighbouring areas in the 1980s (Zonn, 1995; Minoransky \& Gabunshchina, 2001), which adversely affected the steppe biota, the sheep themselves and the life of the communities. In order to restore steppe ecosystems, the State Nature Reserve «Rostovsky» was organised in the Orlovsky district and Remontnensky district of RR in 1995.

The Association «Wild Nature of Steppe» is responsible for the preservation and restoration of steppe biodiversity, preservation of valuable animal species, formation of ecological knowledge and culture among the population (Minoransky et al., 2015). Its Field Stationary is located in the Manych Village of the Orlovsky district of RO in the buffer zone of the Rostovsky Reserve (Fig. 1). It is located on a virginal, neverplowed steppe site that has practically not been used for grazing sheep, horses and other animals in the last 15 years. Since the 1990s, the natural vegetation has been restored, true turmod-cereal steppes (dry) are common, and on the terraces of the Western Manych river - the «valley» variant of these steppes.

It is inhabited by the Bustard (Otis tarda Linnaeus, 1758), Bustling (Tetrax tetrax Linnaeus, 1758), Kulan (Equus hemionus kulan Groves et Mazák, 1967), Saiga (Saiga tatarica), and other animal species.

Researching of the possibility of maintaining Przewalski's horse in the Don steppe began in 2010. Employees of the Association analysed the existing experience with keeping the horses at breeding centres at the Askania-Nova Biosphere Reserve, Prague Zoo and Rostov Zoo, and evaluated the conditions at the Field Stationary. Przewalski's horses were transported from the Askania-Nova Biosphere Reserve. After selection of animals at Askania-Nova Biosphere Reserve, their preparation for transportation, registration of necessary documents, the horses were transported to the Stationary on 28-31 March, 2013. The Station is staffed with a horse care expert, veterinarians, rangers and keepers. Specialists from various scientific centres visit the Stationary to study horses and advise the Association employees on the keeping of Przewalski's horse. The station journal is routinely updated with observations on the behaviour and condition of animals, provisioning, birth time of foals, etc.

Four Przewalski's horses (one male 5 years old, two females 6 years old and one female 4 years old) from the Askania-Nova Biosphere Reserve were transported by the Association's employees by truck. At the Stationary, they were placed in a $40 \mathrm{~m}$ by $50 \mathrm{~m}$ enclosure previously built in the steppe with natural vegetation, fenced with mesh fastened to iron pipe poles. The horses released in it were shy, afraid of humans and kept together in the part farthest from humans over the first weeks. In addition to growing grass, fodder green plants, hay and a dry grain mixture was provided as food, given to the animal in excess. Drinking bowls with water were provided in the enclosure. There was also a covered canopy of $4 \times 5 \mathrm{~m}$ area. The horses were monitored from 2013 to 2018. 


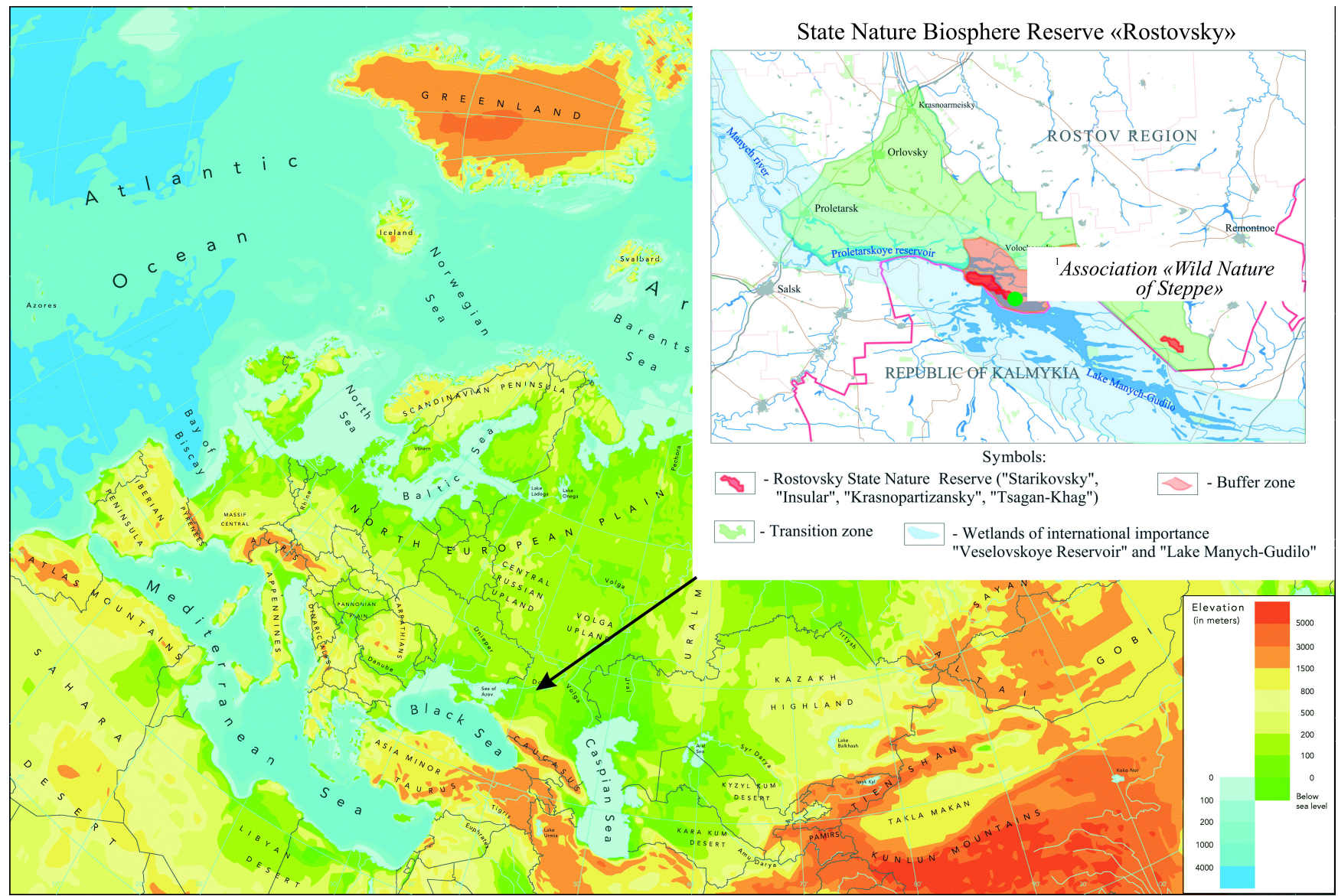

Fig. 1. Map showing location of the Association «Wild Nature of Steppe» Stationary.

\section{Results and Discussion}

After several months of habitation at the acclimatisation enclosure the animals became more accustomed to humans. The first foal was born on 20 October, 2013. When persons or animals appeared near the fence, all the horses surrounded the foal, placing it in the centre of the group. In 2014, an enclosure of $0.63 \mathrm{~km}^{2}$ was built on a steppe site with natural vegetation. It was fenced with metal posts $1.7 \mathrm{~m}$ high, connected by three rows of metal pipes of smaller diameter than the poles. Two wells were drilled in the enclosure, providing gravity-fed water supply to drinking bowls. Mineral licks are available near the drinking bowls. The horses are kept in the enclosure throughout the year. They have become calmer, changed their attitude towards humans. Usually the herd grazes within $300 \mathrm{~m}$ or more from the fence. When humans approach, the stallion leaves the herd, and moves towards humans with raising head. Approaching to $30-50 \mathrm{~m}$, he stops and watch the humans. If they move along the fence, the stallion follows in parallel, neighing. After accompanying humans for about $100-150 \mathrm{~m}$, the stallion returns to the herd which continues grazing.
In 2016-2017, the Station organised a breeding centre for rare and valuable animals with a fenced area of $5.12 \mathrm{~km}^{2}$, and the Przewalski horses were transferred there. In different seasons of the year and during the day they move around the sites of the enclosure, choosing the most favourable forage plants (Fig. 2, Fig. 3).

The natural steppe vegetation in the enclosure is preserved well due to the small number of horses. The animals are constantly provided with salt licks and fresh water. Additional forage is provided to the horses in the enclosure in cold season, mostly during wind and snowfall, when the ground remains covered with snow for a long time.

The forage consists of hay (mainly from meadow and leguminous grasses, mowed near the pen and stacked), some oats and other grains. It is spread in several feeding sites. Sometimes hay is given in the second half of summer, when the steppe vegetation dries completely, as well as in the end of winter and early spring. Throughout the year bran, root crops, green shrubs and other supplementary fodder is provided to the horses and other animals on an irregular basis. 


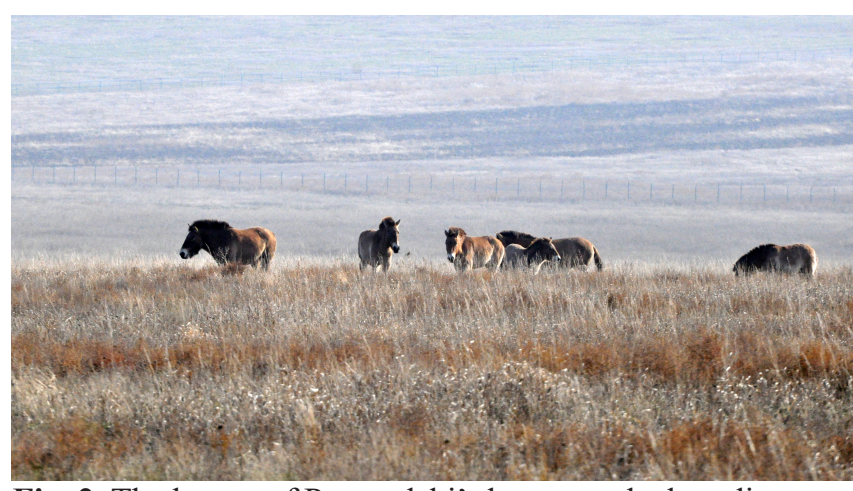

Fig. 2. The harem of Przewalski's horses at the breeding centre of the Association «Wild Nature of Steppe».

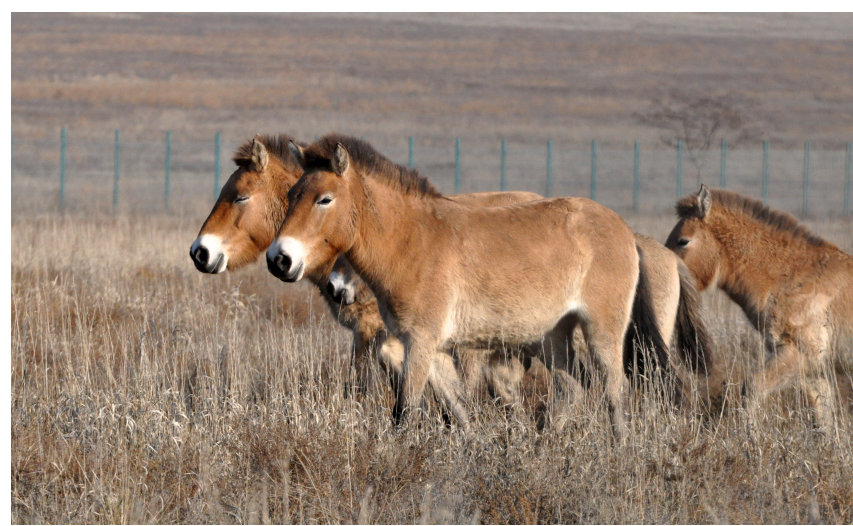

Fig. 3. Przewalski's horses at the breeding centre of the Association «Wild Nature of Steppe».

Optimal living conditions for horses, including satisfactory nutrition are evidenced by: good physical and physiological condition of animals, their behaviour, reproduction, absence of noticeable diseases and deaths in the herd. Every year new foals of Przewalski's horse are born at the Stationary. From 2013 to 2018, nine foals were born here. One of the four horses purchased from the Askania-Nova Reserve in 2013 proved to be pregnant, which means that on 20 October 2013 there were five horses, four adults and one foal. Since October 2013 another nine foals were born, which makes a total of 14 horses in 2018. In 2018, a harem of 11 specimens was kept in the large enclosure, and three males were kept in an isolated pen of $0.3 \mathrm{~km}^{2}$. The growing number of Przewalski's horse in the Association «Wild Nature of Steppe»in 2013-2018 is shown in Fig. 4.

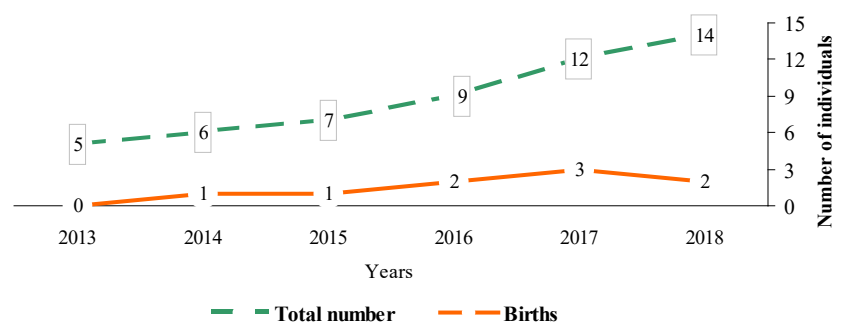

Fig. 4. Dynamics of Equus ferus przewalskii numbers at the breeding centre of the Association «Wild Nature of Steppe» Stationary in 2013-2018.
At the Stationary, observations are made on the keeping of horses in the enclosure together with other animals, e.g. Kulan, Guanaco (Lama guanicoe Linnaeus, 1758), Père David's Deer (Elaphurus davidianus Mulne-Edward, 1866), Water buffalo (Bos bubalis Linnaeus, 1758), Domestic yak (Bos grunniens Linnaeus, 1766), American Bison (Bison bison Linnaeus, 1758). For this purpose, during the warm season, groups of animals were introduced for a certain period (up to 1-3 months) to the enclosure with Przewalski's horse: 8-12 Guanacos, three Père David's Deers, 6-8 Water buffalos, 6-8 Domestic yaks, 8-12 American Bisons. Animals of different species kept distance, occasionally approaching closer, usually without displaying aggression. However, certain species of animals, when staying together in the enclosure, demonstrated some difficulties (instance.g., during calving, when sharing drinking water) for themselves or for Przewalski's horse. Saiga antelopes (Saiga tatarica) seem to be the most suitable ungulate for keeping together with Przewalski's horses. The herd of Przewalski's horse and a herd of 50-60 Saiga antelops lived in the same enclosure for a long time (six months). Observations showed that both the herds may come close to each other and do not compete for forage. Similar relationships have also been observed in meetings of the horses with groups of 10-20 Bactrian camels (Camelus bactrianus Linnaeus, 1758).

Since 2017, the Stationary has been constructing a fence to protect $17.34 \mathrm{~km}^{2}$ steppe plot with natural vegetation. In the future, it is planned to release Przewalski's horses, Saiga antelops and other animals there. The issue of buying new Przewalski's horses or exchange for maintaining genetic diversity in the existing group is under discussion. These and other problems of keeping horses need to be solved in the next few years.

\section{Conclusions}

The Association "Wild Nature of Steppe» deals with the protection and restoration of biodiversity of steppe habitats in European steppes of Russia. Its Field Stationary with an area of $20 \mathrm{~km}^{2}$ is located in a strictly protected area of the State Nature Biosphere Reserve «Rostovsky». It is inhabited by Bustling, Saiga, Guanaco, Père David's Deers, Water buffalo, Domestic yak, American Bison and other species. In 2013, the Association brought from the Askania-Nova Biosphere Reserve four Przewalski's horses and placed them in an acclimatisation enclosure. In 2014, the horses 
were transferred to another enclosure with natural steppe vegetation area of $0.63 \mathrm{~km}^{2}$; in 2017 they were moved to a large enclosure of $5.12 \mathrm{~km}^{2}$. Presently (2018) the Przewalski's horse herd at the Association Stationary consists of 14 specimens, well adapted to local climatic, nutrition and other conditions. It has an area of sufficient size and necessary forage base, and is under the supervision of qualified specialists. Proof of its successful existence is the good physical and physiological condition, successful reproduction and survival of offspring. Experiments with releasing other animals in the same enclosure with E.f. przewalskii showed that Przewalski's horses can successfully coexist for a long time (six months) with small groups of Saiga and Bactrian camel.

\section{References}

Kirikov S.V. 1959. Changes of fauna in the natural zones of the USSR (XIII-XIX centuries): Steppe zone and forest-steppe. Moscow: AN USSR Publishing House. 176 p. [In Russian]
Minoransky V.A., Chekin A.V. 2003. State Steppe Reserve «Rostovsky». Rostov-on-Don: Publishing house LLC «TsVR». 129 p. [In Russian]

Minoransky V.A., Dankov V.I., Tolcheeva S.V., Malinovskaya Yu.V., Bezuglova E.A. 2015. Association «Wildlife of the Steppe» and its role in the protection of the biological resources of the Don. Rostov-on-Don: Foundation. 104 p. [In Russian]

Minoransky V.A., Gabunshchina E.B. 2001. Unique ecosystems: Lake Manych-Gudilo. Elista: Dzhungar. 239 p. [In Russian]

Panov V.D., Bazelyuk A.A., Lurje P.M. 2009. Rivers West and East Manych. Hydrography and flow mode. Rostov-on-Don: Don Book House. 432 p. [In Russian]

Spasskaya N.N. 2016. Preservation and restoration of Przewalski's horse: dizziness from success? Steppe Bulletin 46: 50-56. [In Russian]

Zimmermann W. 2005. Przewalskipferde auf dem Weg zur Wiedereinbürgerung - Verschiedene projekte im vergleich. Zeitschrift des Kolner Zoo 48(4): 183-209.

Zonn I.S. 1995. Republic of Kalmykia - Halmg-Tangch European region of ecological tension. In: Biota and Natural Environment of Kalmykia. Moscow - Elista: Korkis LLP. P. 6-18. [In Russian]

\title{
ОПЫТ СОДЕРЖАНИЯ ЛОШАДИ ПРЖЕВАЛЬСКОГО (EQIUDAE, PERISSODACTYLA) В ПИTOMНИКE АССОЦИАЦИИ «ЖИВАЯ ПРИРОДА СТЕПИ» (РОССИЯ)
}

\author{
В. А. Миноранский ${ }^{1,2, *}$ А. М. Узденов ${ }^{1}$ В. И. Даньков ${ }^{1}$, Ю. В. Малиновская ${ }^{1,2, * *}$ \\ ${ }^{1}$ Ассоџиащия «Живая природа степи», Россия \\ *e-mail: priroda.rostov@yandex.ru \\ ${ }^{2}$ Южный федеральный университет, Россия \\ **e-mail:mgingerm@yandex.ru
}

\begin{abstract}
Ассоциация «Живая природа степи» находится в Ростовской области (Россия) и занимается сохранением редких и ценных животных степной зоны. Питомник Ассоциации расположен в охранной зоне Государственного природного биосферного заповедника «Ростовский» В ее питомнике (площадь 17.34 км ${ }^{2}$ ) живут дрофа (Otis tarda), стрепет (Tetrax tetrax), кулан (Equus hemionus kulan), сайгак (Saiga tatarica) и другие виды животных. Тарпан (Equus ferus ferus) обитал в европейских степях до ХІХ в. В 2013 г. Ассоциация «Живая природа степи» приобрела в Биосферном заповеднике «Аскания-Нова» им. Ф.Э. Фальц-Фейна (Украина), одного самца лошади Пржевальского (Equus ferus przewalskii) в возрасте пяти лет, две самки шести лет и одну самку четырех лет. В статье рассмотрены перевозка лошадей в Ростовскую область, их акклиматизация и содержание. Лошадей первоначально разместили в карантинном во-

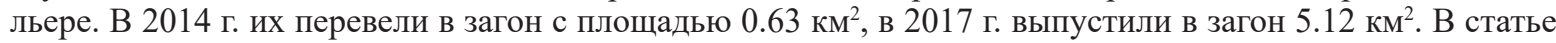
дается характеристика вольера и загонов, питания лошадей, их поведение. В питомнике Ассоциации «Живая природа степи» животные ежегодно размножаются. В настоящее время их количество составляет 14 особей. Данная ситуация свидетельствует об относительно благоприятных условиях на территории обитания животных. Три молодых самца содержатся отдельно от основного табуна. В питомнике проводились исследования по содержанию лошадей совместно с другими животными: куланом, гуанако (Lama guanicoe), оленем Давида (Elaphurus davidianus), азиатским буйволом (Bos bubalis), яком (Bos grunniens), бизоном (Bison bison) и другими. Лошадь Пржевальского живет успешно с сайгаком и двугорбым верблюдом (Camelus bactrianus). В дальнейшем планируется расширить площадь загона для лошадей и приобрести новых особей для генетического обновления группировки животных.
\end{abstract}

Ключевые слова: Equus ferus przewalskii, заповедник, разведение, Ростовская область, экологический туризм 